\title{
Streamflow trends in Europe: evidence from a dataset of near-natural catchments
}

\author{
K. Stahl ${ }^{1,2}$, H. Hisdal ${ }^{3}$, J. Hannaford ${ }^{4}$, L. M. Tallaksen ${ }^{1}$, H. A. J. van Lanen ${ }^{5}$, E. Sauquet ${ }^{6}$, S. Demuth $^{7}$, \\ M. Fendekova ${ }^{8}$, and J. Jódar ${ }^{9}$ \\ ${ }^{1}$ Department of Geosciences, University of Oslo, Oslo, Norway \\ ${ }^{2}$ Institute of Hydrology, University of Freiburg, Freiburg, Germany \\ ${ }^{3}$ Norwegian Water Resources and Energy Directorate, Oslo, Norway \\ ${ }^{4}$ Centre for Ecology and Hydrology, Wallingford, UK \\ ${ }^{5}$ Hydrology and Quantitative Water Management Group, Centre for Water and Climate, Wageningen University, \\ Wageningen, The Netherlands \\ ${ }^{6}$ UR Hydrologie-Hydraulique Cemagref, Lyon, France \\ ${ }^{7}$ Division of Water Sciences, Section of Hydrological Processes and Climate, Natural Sciences Sector, UNESCO, \\ Paris, France \\ ${ }^{8}$ Department of Hydrogeology, Faculty of Natural Sciences, Comenius University in Bratislava, Bratislava, Slovakia \\ ${ }^{9}$ Institute of Environmental Assessment and Water Research (IDAEA-CSIC), Barcelona, Spain
}

Received: 9 August 2010 - Published in Hydrol. Earth Syst. Sci. Discuss.: 16 August 2010

Revised: 10 November 2010 - Accepted: 18 November 2010 - Published: 1 December 2010

\begin{abstract}
Streamflow observations from near-natural catchments are of paramount importance for detection and attribution studies, evaluation of large-scale model simulations, and assessment of water management, adaptation and policy options. This study investigates streamflow trends in a newly-assembled, consolidated dataset of near-natural streamflow records from 441 small catchments in 15 countries across Europe. The period 1962-2004 provided the best spatial coverage, but analyses were also carried out for longer time periods (with fewer stations), starting in 1932, 1942 and 1952. Trends were calculated by the slopes of the Kendall-Theil robust line for standardized annual and monthly streamflow, as well as for summer low flow magnitude and timing. A regionally coherent picture of annual streamflow trends emerged, with negative trends in southern and eastern regions, and generally positive trends elsewhere. Trends in monthly streamflow for 1962-2004 elucidated potential causes for these changes, as well as for changes in hydrological regimes across Europe. Positive trends were found in the winter months in most catchments. A marked shift towards negative trends was observed in April, gradually spreading across Europe to reach a maximum extent
\end{abstract}

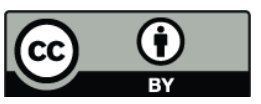

Correspondence to: K. Stahl (kerstin.stahl@ hydrology.uni-freiburg.de) in August. Low flows have decreased in most regions where the lowest mean monthly flow occurs in summer, but vary for catchments which have flow minima in winter and secondary low flows in summer. The study largely confirms findings from national and regional scale trend analyses, but clearly adds to these by confirming that these tendencies are part of coherent patterns of change, which cover a much larger region. The broad, continental-scale patterns of change are mostly congruent with the hydrological responses expected from future climatic changes, as projected by climate models. The patterns observed could hence provide a valuable benchmark for a number of different studies and model simulations.

\section{Introduction}

Elucidating regional patterns of hydrological change has become one of the most important challenges in contemporary hydrology. Reliable information on such patterns, beyond the river basin or national scale, enables the identification and attribution of changes in flow regimes influenced by largescale processes such as climate change. However, direct anthropogenic disturbances (e.g. abstractions, discharges and reservoir releases) and indirect impacts of land use change have modified river flow regimes across the globe (e.g. Döll

Published by Copernicus Publications on behalf of the European Geosciences Union. 
et al., 2009), confounding the identification of climate-driven changes. Hannah et al. (2010) emphasize, therefore, that data requirements for climate change detection studies are demanding; they should be based on good quality data from observation networks of rivers with near-natural conditions.

Several countries have recently established so-called "reference" or "benchmark" networks. In general, streamflow records from these networks represent near-natural river flow regimes from catchments with different hydrological characteristics, usually taken to be representative of wider regions. They thus provide a basis for investigating the predominant climate and catchment processes that govern changes in regional hydrology. A further advantage of such networks is that the gauged catchments are typically small, by virtue of the need to minimise the impact of human disturbance. In larger catchments, processes with opposing hydrological influences may act simultaneously. For example, as a response to a warming trend in early summer, snowmelt in a catchment's mountain headwaters may increase but higher evapotranspiration in lowland regions may counter this effect, hence resulting in no net change at the downstream gauging station. Data from such "reference" networks are therefore of fundamental importance for detection and attribution studies and for validation of large-scale climate and hydrological models. In North America, accounts of hydrological change have capitalized on reference river basin networks such as the US Hydro-Climatic Data Network (HCDN) of $>1600$ minimally disturbed catchments (Slack and Landwehr, 1992), or the Canadian Reference Hydrometric Basin Network RHBN (Harvey et al., 1999). These data have been used in many previous studies of trends in North America (e.g. Lins and Slack, 1999; Douglas et al., 2000; Zhang et al., 2001; Burn et al., 2010) and have recently found application in climate change attribution studies (Krakauer and Fung, 2008). Such data have also played a major role in the calibration or validation of large-scale hydrological models (Lohmann et al., 2004; Troy et al., 2008), which can then be used to systematically study processes of change (e.g. Hamlet et al., 2007).

The need for a reference dataset of near-natural streamflow records in Europe was recognised by the FRIEND programme, an initiative under the UNESCO International Hydrological Programme (IHP), which established the European Water Archive (EWA) (details see Sect. 2). The EWA dataset has been used for many international studies; for example, Hisdal et al. (2001) investigated trends in streamflow droughts across Europe (the study was recently updated with the dataset applied herein; Stahl et al., 2008), and Shorthouse and Arnell (1997) examined links between streamflow and large-scale atmospheric circulation. However, the establishment and regular update of a streamflow reference network for Europe is complicated by the many jurisdictions responsible for data gathering and their willingness to share data nationally as well as internationally. There are many reasons for this, including political, administrative and technical constraints (Hannah et al., 2010) as well as economic barriers (Viglione et al., 2010). In the absence of a widely available and up-to-date reference network, data from global databases, foremost from the Global Runoff Data Centre (GRDC), have often been used to study: (i) hydrological changes globally, including Europe (e.g. Milliman et al., 2008), and (ii) to validate large-scale land surface models and hydrological models (e.g. Hunger and Döll, 2008; Haddeland et al., 2010). The GRDC dataset includes streamflow records of variable length, mostly from large continental river basins which typically have heavily altered hydrological regimes (Nilsson et al., 2005). To minimize the impact of anthropogenic disturbances, most studies only considered annual streamflow and, in addition, used models to fill in gaps or establish time series of comparable length (Milly et al., 2005; Dai et al., 2009). Few studies have examined seasonal changes or extremes.

Reference networks have been established in some European countries. Trends in low and high flows have been examined in the UK (Hannaford and Marsh, 2006, 2008), based on a "benchmark" network (Bradford and Marsh, 2003). A regional reference dataset was recently collated for the Nordic and Baltic countries, and used to study trends in annual and seasonal flows, floods and droughts (Hisdal et al., 2007). Apart from these studies, however, European countries appear not to have developed (or at least have not promoted) streamflow datasets that can be used to describe nearnatural regional hydrology. This is primarily because, in comparison with North America where many catchments can justifiably be called "pristine", a true natural network is much more difficult to establish in Europe due to the higher population density, an associated lack of natural landscape and a long history of water infrastructure development. However, the large number of trend studies that have been carried out on regional or national scales testifies to the usefulness of at least parts of the national networks including, for example, France (Renard et al., 2008), southern Germany (KLIWA, 2003), Switzerland (Birsan et al., 2005; Schmocker-Fackel et al., 2010), Slovakia (Majercakova et al., 1997; Demeterova and Skoda, 2005, 2009), the Czech Republic (Fiala, 2008; Fiala et al., 2010) and Spain (Beguería et al., 2003; MoránTejeda et al., 2010).

These studies all report considerable spatial variability in the changes detected in streamflow, and results are sensitive to the selection of data, trend detection method, and the time period chosen. Hence, it is challenging to combine the results of such regional and national trend studies into a pan-European account of hydrological change. There is, therefore, a need for a comprehensive pan-European study that uses a consistent methodology on a consolidated "bestpossible" European reference dataset. Such a well-founded overview of recent changes in small near-natural catchments, that are representative of regional hydrological regimes and water balance across Europe, would be of great interest and benefit to the scientific community and policymakers alike. Detection and attribution of emerging trends is vital for 
formulating appropriate policy responses, and for enabling the verification of current climate and hydrological simulations. Furthermore, such an appraisal provides a "baseline" against which both climate change projections and observed future climate changes can be compared.

The purpose of this study is to provide an observational account of the evolution of European streamflow through the greater part of the 20th and early 21 st centuries, with a particular emphasis on flow regime characteristics relevant for water resources management (i.e. annual, monthly and low flows). By applying a consistent methodology across Europe, to a set of catchments meeting specific criteria, the study aims for a detailed characterisation of regional patterns of streamflow changes. This complements recent reports on changes and trends in precipitation, temperature and climatic water balance and supports the discussion on how these trends can explain observed changes in surface hydrology. Special emphasis is given to changes in streamflow regimes as represented by monthly mean flow and how these vary across different hydroclimatological regions, including temporal shifts that are known to affect snow-dominated regimes. Changes detected in the monthly flows are further used to improve understanding of the likely causes of observed changes in annual and low flows. Firstly, the newly assembled streamflow dataset is presented (Sect. 2), followed by a description of the methodology to calculate trends in different streamflow indices (Sect. 3) and a summary and visualization of these trends for Europe and its regions (Sect. 4). The discussion in Sect. 5 compares the trends in hydrology with observed changes in climate and, where applicable, refers to comparable findings in regional and national studies. Finally, the results are discussed in light of recent climate change predictions for Europe.

\section{A data set of near-natural streamflow records from small catchments}

The only existing consolidated dataset of European streamflow observations suitable for the assessment of spatial variations in regional hydrology is UNESCO's European Water Archive (EWA), a dataset that underpins much of the research undertaken within the international research programme FRIEND (Flow Regime from International Experiment and Network Data). This archive of the EUROFRIEND sub-network (http://ne-friend.bafg.de) provided the core for this analysis. While containing records from about 3800 gauging stations, from more than 29 European countries, the database relies on voluntary contribution of data, and a mechanism for regular updates has yet to be found. The database, which is now held at the Global Runoff Data Centre (www.grdc.bafg.de/ewa), is available to all active members of the FRIEND network. As a basis for this study, the authors, in a collaborative effort as part of the EU WATCH (Water and Global Change) project, updated the database for some, but not all European countries. Whilst a significant majority of updates were extensions to existing EWA records, in some cases entirely new sets of gauging stations were added where they were more appropriate; in the UK, for example, the UK Benchmark Network was incorporated rather than using previous EWA stations. The update and data collection required the help of many national or regional agencies responsible for collecting streamflow data in individual countries, as further described in Stahl et al. (2008) and Hannah et al. (2010). Criteria were:

- Homogeneous, quality controlled records of daily mean flow;

- suitability for low flow analysis, including no appreciable direct human influence on river flow during low flow (e.g. through abstractions, reservoir storage);

- small catchments with areas generally not exceeding $1000 \mathrm{~km}^{2}$ - however, some slightly larger basins were included, where there was a significant justification for improving spatial coverage (Table 1);

- time series should cover 40 years or longer and include recent data, at least to the year 2004.

In general, the national institutions that supplied data also provide quality control services, including detection and infilling of missing values; no further modifications to the records were made. However, all records were screened visually and those with visible inhomogeneities, problems in the low flow range, or mislabelled missing values (e.g. with zeros) were excluded. In this study, high flows were not investigated because the selection criteria prioritised low flows. Table 1 gives an overview of the dataset in terms of the number of stations per country for different time periods. The number of records from each country varies from one or a few (e.g. the Netherlands) to over two hundred (e.g. Germany). The table also lists the data sources and provides access possibilities for other studies (i.e. EWA data are available for FRIEND members).

A consistent regional trend study requires the use of the same reference period for all time-series included. The aim was hence to use as many stations as possible, balancing the requirement for a high number of stations (allowing good geographical coverage) with the need for sufficiently long time series to represent historical variability. After a final quality check, 441 gauging stations in 15 countries, covering the period 1962-2004 (with no more than 3 years of missing data), remained. The number of available records and geographical coverage decreases strongly for longer periods. Reasons for a lack of data from some European countries are diverse. For some countries, time series longer than the required minimum of 40 years were not available, some countries were unable to provide data at no cost, in some countries streamflow archives are local and no central database exists for larger 
Table 1. Streamflow dataset.

\begin{tabular}{|c|c|c|c|c|c|c|c|}
\hline \multirow[t]{2}{*}{ Country } & \multicolumn{4}{|c|}{ No. of records } & \multirow{2}{*}{$\begin{array}{c}\text { Catchment } \\
\text { area } \\
\text { Mean } \\
\left(\mathrm{km}^{2}\right)^{*}\end{array}$} & \multirow[t]{2}{*}{ Data Source } & \multirow{2}{*}{$\begin{array}{l}\text { Contribution or } \\
\text { Access** }\end{array}$} \\
\hline & $\begin{array}{r}1962- \\
2004\end{array}$ & $\begin{array}{r}1952- \\
2004\end{array}$ & $\begin{array}{r}1942- \\
2004\end{array}$ & $\begin{array}{r}1932- \\
2004\end{array}$ & & & \\
\hline Austria & 47 & 32 & 1 & 0 & 206 & $\begin{array}{l}\text { Federal Ministry of } \\
\text { Agriculture, Forestry, } \\
\text { Environment and Water } \\
\text { Management }\end{array}$ & $\begin{array}{l}\text { EWA/ } \\
\text { http:gis.lebensministerium.at/ehyc }\end{array}$ \\
\hline $\begin{array}{l}\text { Czech } \\
\text { Republic }\end{array}$ & 14 & 11 & 11 & 9 & 288 & $\begin{array}{l}\text { Czech Hydrometeorologic } \\
\text { Institute }\end{array}$ & EWA \\
\hline Denmark & 19 & 16 & 13 & 8 & 268 & $\begin{array}{l}\text { National Environmental } \\
\text { Research Institute - Denmark }\end{array}$ & EWA \\
\hline Estonia & 4 & 0 & 0 & 0 & 374 & $\begin{array}{l}\text { Estonian Meteorological and } \\
\text { Hydrological Institute }\end{array}$ & this study \\
\hline Finland & 5 & 4 & 4 & 2 & 2059 & $\begin{array}{l}\text { Finnish Environment } \\
\text { Institute }\end{array}$ & EWA \\
\hline France & 68 & 36 & 18 & 12 & 754 & HYDRO database & $\begin{array}{l}\text { WATCH/ } \\
\text { http:hydro.eaufrance.fr }\end{array}$ \\
\hline Germany & 137 & 80 & 43 & 33 & 292 & $\begin{array}{l}\text { Environment Agencies of the } \\
\text { Federal States*** }\end{array}$ & EWA \\
\hline Lithuania & 5 & 0 & 0 & 0 & 710 & $\begin{array}{l}\text { Lithuanian } \\
\text { Hydrometeorological Service }\end{array}$ & this study \\
\hline $\begin{array}{l}\text { Nether- } \\
\text { lands }\end{array}$ & 1 & 0 & 0 & 0 & 351 & Water Board Rijn and IJssel & EWA \\
\hline Norway & 40 & 40 & 40 & 36 & 416 & $\begin{array}{l}\text { Norwegian Water Resources } \\
\text { and Energy Directorate }\end{array}$ & EWA \\
\hline Slovakia & 19 & 18 & 18 & 17 & 231 & $\begin{array}{l}\text { Slovak Hydrometeorological } \\
\text { Institute }\end{array}$ & WATCH \\
\hline Spain & 14 & 11 & 1 & & 452 & $\begin{array}{l}\text { CEDEX (Centro de Estudios } \\
\text { y Experimentacion de Obras } \\
\text { Publicas) }\end{array}$ & $\begin{array}{l}\text { WATCH/ } \\
\text { http://hercules.cedex.es }\end{array}$ \\
\hline Sweden & 9 & 9 & 8 & 5 & 1194 & $\begin{array}{l}\text { Swedish Meteorological and } \\
\text { Hydrological Institute }\end{array}$ & EWA \\
\hline $\begin{array}{l}\text { Switzer- } \\
\text { land }\end{array}$ & 23 & 14 & 11 & 9 & 164 & $\begin{array}{l}\text { Bundesamt für Umwelt } \\
\text { BAFU }\end{array}$ & EWA \\
\hline UK & 36 & 6 & 3 & 1 & 383 & $\begin{array}{l}\text { UK National River Flow } \\
\text { Archive, Centre for } \\
\text { Ecology and Hydrology }\end{array}$ & EWA \\
\hline Total & 441 & 277 & 171 & 132 & & & \\
\hline
\end{tabular}

* Based on catchments with data for the 1962-2004 period.

** Indicates contribution to (i) this study: data provided and permission granted from the source only for this study; (ii) EWA: stored in EWA and accessible to all active members of FRIEND (http://grdc.bafg.de/); (iii) WATCH: provided for use within the EU project WATCH.

*** Landesanstalt für Umwelt, Messungen und Naturschutz, Baden-Württemberg; Sächsisches Landesamt für Umwelt und Geologie; Bayerisches Landesamt für Umwelt; Thüringer Landesanstalt für Umwelt und Geologie, Niedersächsischer Landesbetrieb für Wasserwirtschaft, Küsten- und Naturschutz; Landesamt für Umwelt, Wasserwirtschaft und Gewerbeaufsicht Rheinland-Pfalz; Hessisches Landesamt für Umwelt und Geologie. 
administrative regions, and finally some countries were not contacted as no contact person could be identified.

For visualisation purposes, results are plotted on maps using catchment boundaries, to provide some indication of how representative the river flow trends are of a wider area. Approximate catchment outlines based on the pan-European River and Catchment Database CCM2 (Catchment Characterisation and Modelling, Version 2; Vogt et al., 2007) were available. The European Joint Research Centre (JRC) established this river network and catchment database based on SRTM (Shuttle Radar Topography Mission) elevation data. Further details of the derivation of the catchment outlines are given in Stahl et al. (2010). In the case of records from nested catchments only the larger catchment was chosen, unless it exceeded $1000 \mathrm{~km}^{2}$ in which case only the record from a smaller subcatchment was used.

\section{Methods}

\subsection{Streamflow indices}

The study investigated the evolution of annual and monthly flow characteristics over the periods 1962-2004, 1952-2004, 1942-2004 and 1932-2004. The following low flow characteristics (indices) were calculated based on the original time series of daily average streamflow:

- May-November AM(7): the 7-day minimum streamflow for each year, derived for the summer period May to November;

- May-November AM(7) timing: the calendar day on which the lowest 7-day streamflow occurred each year, derived for the summer period May to November;

- May-November $\operatorname{AM(30):~same~as~} \operatorname{AM}(7)$, only for 30 days.

The reason for choosing the May-November period for calculating low flow indices is to ensure only summer low flows (driven by low rainfall/high evapotranspiration) are considered, and not winter low flows caused by storage in ice and snow. Mixing processes in this way would hamper the interpretation of the results. However, the month of annual minimum, i.e. the selected calendar month with the lowest average monthly streamflow, was derived for the period 19622004 , to assess changes in the mean flow of this month (hereafter referred to as the regime minimum trend). This allows separate regime types, i.e. both summer and winter low flow regimes, to be integrated into a single analysis.

Observed changes in mean annual flow are discussed in light of changes in mean monthly flows, whereas changes in low flows are compared with changes in the annual minimum flow (absolute value and timing). Two different temporal windows (averaging intervals) were used, both of which are widely-used low flow statistics. The different periods reflect slightly different facets of the low flow regime; seven days provides a "true" low flow value, whereas 30 days compares with the monthly mean and is an indicator of extendedduration low flow or drought periods (particularly in flashy catchments), and therefore important from a water resource perspective.

\subsection{Trend magnitude}

Trend magnitudes were estimated from the slope of the Kendall-Theil robust line (Theil, 1950). As described in e.g. Déry et al. (2005), a linear equation is developed from the time series of annual streamflow indices $y$ with time $t$ as:

$y=m t+b$

where $m$ is the slope and $b$ is the intercept. The slope $m$ is calculated as the median of all slopes $m_{k}$ of consecutive pairs of values:

$m_{k}=\frac{\left(y_{j}-y_{i}\right)}{\left(t_{j}-t_{i}\right)}$

where $k=1,2, \ldots, n(n-1) / 2 ; i=1,2, \ldots, n-1$; and $j=2$, $3, \ldots, n$. This slope is also often referred to as the Sen Slope (Sen, 1968).

The slopes were calculated from time series of the standardized streamflow indices to allow comparison of trend magnitudes across the European stations. Thus, the slope is expressed in standard deviations per year. This measure of slope has been applied previously to compare trends in different variables across regions and hydrological regimes (Déry et al., 2009).

The application of trend tests has been discussed widely in the literature, and in the recent past there has been some controversy over the applicability of trend tests to hydroclimatic time series (e.g. Cohn and Lins, 2005; Radziejewski and Kundzewicz, 2004; Svensson et al., 2006; Clarke, 2010). In particular, the underlying assumptions of the hypotheses of trend tests, i.e. an independent and identically distributed (IID) random variable or an autoregressive (AR) process have been questioned (Cohn and Lins, 2005; Koutsoyiannis and Montanari, 2007). Several studies have shown that streamflow does not behave as an IID or AR process, but tends to exhibit long-term persistence (LTP) and variability (e.g., von Storch, 1995; Koutsoyiannis, 2003, 2006; Khaliq et al., 2008; Chen and Grasby, 2009). In addition, there are concerns about the power of various tests in the presence of auto and cross-correlation (Yue and Wang, 2002; Hamed and Rao, 1998). However, testing of statistical significance is not the aim of this study; rather, the paper aims to present the overall regional patterns of streamflow evolution over particular time periods, focusing on co-variability in space and across variables, rather than being concerned with the type of change, i.e. whether the trend is monotonic, linear or nonlinear, or perhaps part of a longer-term oscillation. 
Table 2. Percentage of positive and negative trends.*

\begin{tabular}{|c|c|c|c|c|c|c|c|c|}
\hline \multirow{2}{*}{$\begin{array}{l}\text { Period } \\
\text { Trend }\end{array}$} & \multicolumn{2}{|c|}{ 1962-2004 } & \multicolumn{2}{|c|}{ 1952-2004 } & \multicolumn{2}{|c|}{ 1942-2004 } & \multicolumn{2}{|c|}{ 1932-2004 } \\
\hline & Pos. & Neg. & Pos. & Neg. & Pos. & Neg. & Pos. & Neg. \\
\hline Annual flow & 30.4 & 30.2 & 32.1 & 27.8 & 48.5 & 19.9 & 36.4 & 24.2 \\
\hline \multicolumn{9}{|l|}{ Monthly flow } \\
\hline Jan & 64.3 & 7.2 & 50.9 & 10.8 & 53.8 & 5.8 & 47.7 & 9.1 \\
\hline Feb & 54.4 & 11.7 & 46.2 & 16.2 & 38.6 & 9.4 & 25 & 8.3 \\
\hline Mar & 52.6 & 19.8 & 45.5 & 16.2 & 39.2 & 11.1 & 40.2 & 13.6 \\
\hline Apr & 13.5 & 55.1 & 20.6 & 28.5 & 24 & 23.4 & 20.5 & 20.5 \\
\hline May & 10.8 & 55.5 & 22.7 & 27.8 & 43.3 & 9.4 & 39.4 & 11.4 \\
\hline Jun & 7 & 60.8 & 7.9 & 44.8 & 15.8 & 28.1 & 9.1 & 34.8 \\
\hline Jul & 11 & 34.2 & 6.9 & 40.8 & 14 & 16.4 & 7.6 & 21.2 \\
\hline Aug & 6.8 & 47.2 & 7.6 & 55.6 & 13.5 & 17.5 & 8.3 & 32.6 \\
\hline Sep & 17.8 & 23 & 17.7 & 22.7 & 27.5 & 15.2 & 9.1 & 12.9 \\
\hline Oct & 35.6 & 13.5 & 23.8 & 19.1 & 35.7 & 16.4 & 13.6 & 14.4 \\
\hline Nov & 26.5 & 9.4 & 33.2 & 8.3 & 28.1 & 7 & 15.9 & 15.2 \\
\hline Dec & 44.3 & 7.4 & 35.7 & 12.3 & 43.3 & 11.1 & 45.5 & 12.9 \\
\hline \multicolumn{9}{|c|}{ Low flow indices } \\
\hline Min. month & 26.9 & 25.6 & 24.9 & 28.9 & 40.9 & 11.1 & 24.2 & 15.2 \\
\hline $\operatorname{AM}(7)$ & 23.3 & 45.6 & 28.4 & 44.7 & 48.5 & 24 & 36 & 30.4 \\
\hline AM(7) Timing & 15.7 & 43.1 & 14.4 & 35.8 & 18 & 26.3 & 20 & 15.2 \\
\hline $\mathrm{AM}(30)$ & 24 & 41.7 & 29.2 & 42 & 50.3 & 20.4 & 34.4 & 27.2 \\
\hline
\end{tabular}

* Counting only trend slopes $>|0.1|$ (standard deviations per year)

To serve as a reference for future studies, trend magnitudes are tabulated for the entire data set and visualised on maps. The main focus is on the period 1962-2004 for which the number of records is greatest. However, all four defined periods were analysed and the results can be used to assess whether trends are sensitive to the time period studied.

\section{Results}

\subsection{Annual streamflow}

Table 2 demonstrates that, for all study periods, the percentage of positive annual streamflow trends (towards wetter conditions) exceeds the percentage of negative trends (towards drier conditions). For the two more recent periods the difference between the proportion of positive and negative trends is smaller, and is particularly marginal for 1962-2004. About one third of the catchments have very weak or no trends. The spatial distribution of these trends is distinct (Fig. 1), with negative trends found in two geographical regions: one is the southwest of the domain, i.e. Spain and southern France, and the other is the central to eastern edge of the domain, i.e. parts of Austria and Germany, the Czech Republic, and Slovakia. Local negative trends were also found in Norway and Finland. Weak or no trends are found mostly in Switzerland, Austria and France. Although for the longer periods
(1932-2004 and particularly 1942-2004) the percentage of positive trends found is higher (Table 2), the general regional pattern of trend directions appears to be fairly stable for the different periods analysed (Fig. 1). However, in Norway the two long periods show more negative trends than the shorter periods. In southern France negative trends are visible in all but the period 1942-2004. The higher percentage of positive trends in the 1942-2004 period reflects the shift in trend in some regions, but also the regions for which longer records were available. These primarily include the countries where positive trends also dominate the shorter periods (e.g. in Switzerland, southern Germany, Denmark) whereas long series were not available in countries such as Spain and Austria, where negative trends were more abundant in the shorter periods.

\subsection{Monthly streamflow}

The analysis of changes in monthly mean flow provides much greater temporal detail, and can help reveal and understand the cause of changes in annual patterns (Fig. 1). For the entire dataset, over the period 1962-2004, positive trends dominate the winter period from October to March, whereas negative trends dominate the summer period from April to September (Table 2). In most countries, from January to June and in August, only about a third of the records 

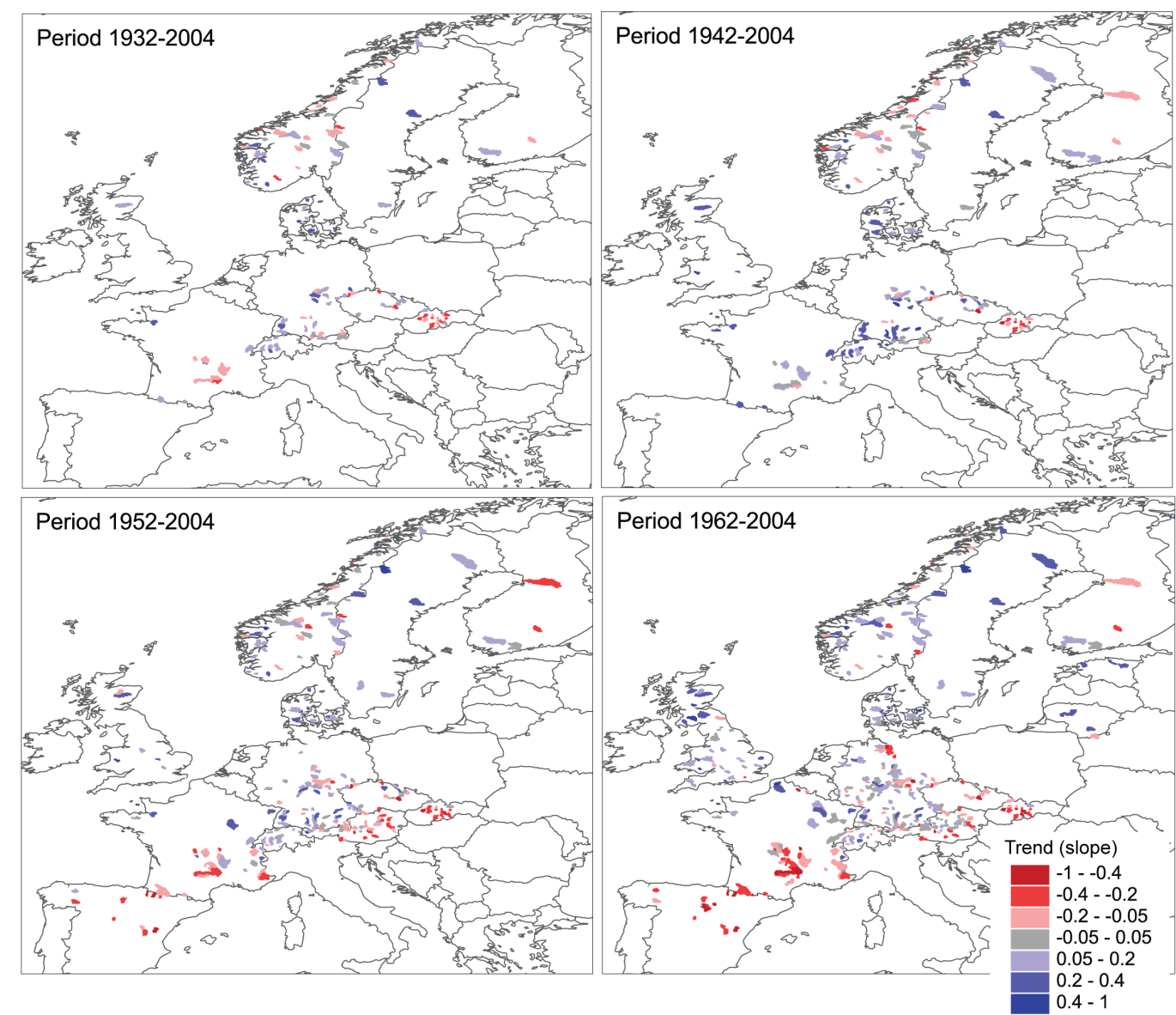

Fig. 1. Trends in annual streamflow for four different periods (trends are given in standard deviations per year).

have weak or no trends, whereas in July and from September to December more than half of the records have weak or no trends. Figure 2 shows the corresponding maps of monthly trends. Regional trend patterns are, to a high degree, coherent throughout the December to February period: the pattern is characterized by negative trends along the southern and eastern borders of the study area (Spain, Southern France, Eastern Austria and the Czech Republic, Slovakia, and two easternmost Finnish stations) and positive trends for northern, western and central Europe, which are particularly strong and coherent in January and February. Denmark is the exception to this pattern, where trends are still negative in December (positive in January and February). For March, positive trends are generally still prevalent across most of the northern and central areas, but the region of negative trends is more widespread, extending across much of France and into the southern UK. In April, the pattern of regional trends changes completely: negative trends dominate across Europe with the exception of Norway and northern Sweden, where trends are strongly positive, and the UK, where trends are weak and mixed. In May, the negative trends are generally weaker than in April but the area of negative trends expands into the UK and Norway. Broadly similar patterns follow in
June, although trends are weaker and more mixed around the North and Baltic seas. In July and August negative trends still dominate (except in Switzerland and southern Germany in July and in Norway, Sweden and Finland in both months). In September, the regional pattern of trends changes again substantially. Now central Europe shows a mix of positive, negative and no trends, while trends remain negative in the UK (strongly so in some catchments) and southwestern Europe. The same applies to east Austria, the Czech Republic and Slovakia, where trends remain negative until November or December. In October there is a strong pattern of positive trends across most of the domain (particularly in central, Alpine areas); in contrast, records from northern and western Norway show predominantly strong negative trends. In November, positive (albeit weaker) trends dominate, with isolated and weak negative trends in some areas.

A few catchments maintain a similar trend all year round. Two records from northern France have positive trends in all months and several Slovak and some Spanish stations have negative trends all year. Overall, the regional patterns across Europe described were found to be quite stable for the different periods analyzed. The results in Table 2 attest to broadly similar patterns in monthly trends between 

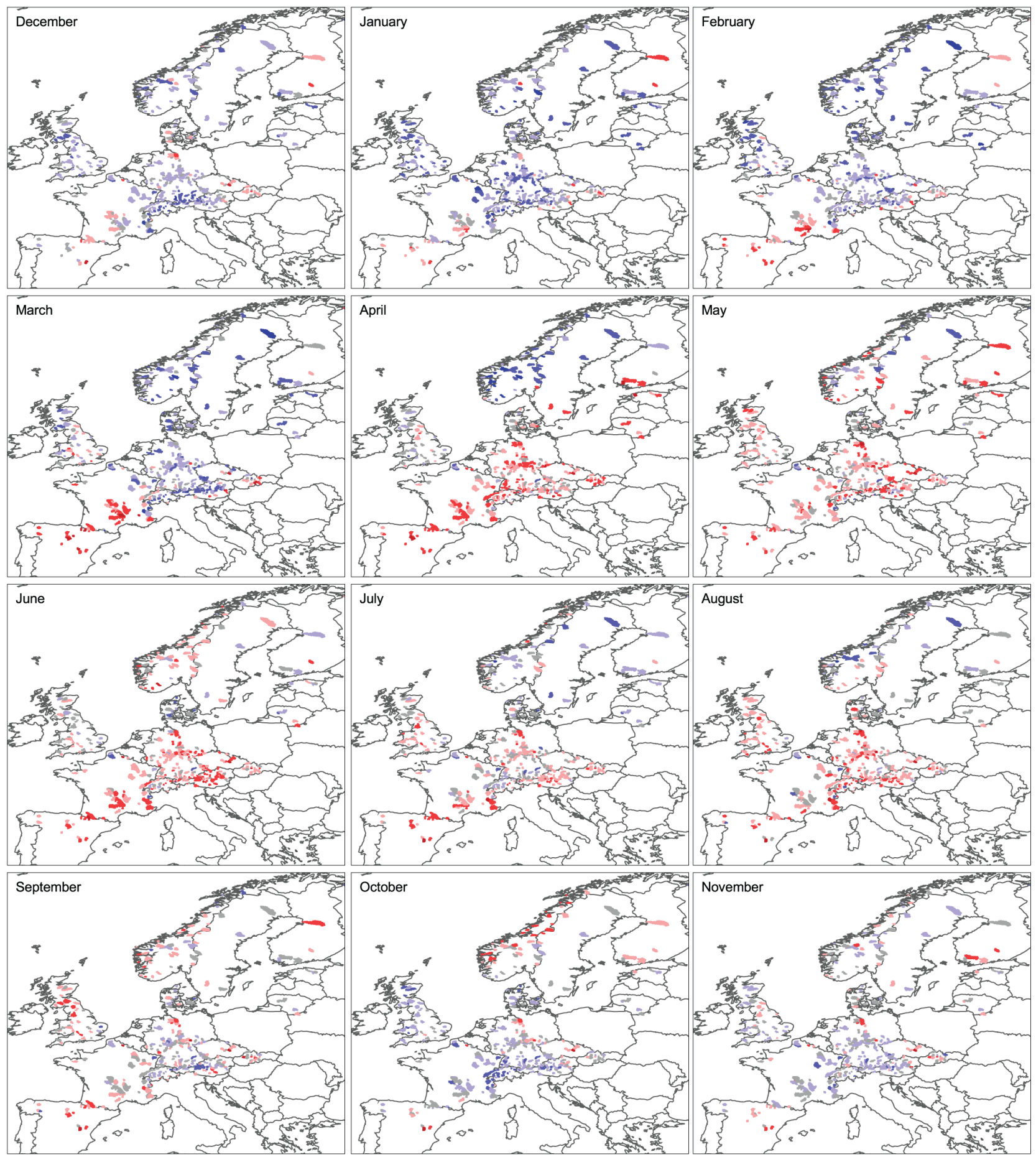

Fig. 2. Trends in monthly streamflow for the period 1962-2004 (legend as in Fig. 1).

the periods, with a consistent pattern of winter increases and summer decreases, but the sparsity of the data precludes a detailed spatial examination.

\subsection{Low flow}

In most of western and central Europe, the month with the lowest flow (regime minimum) occurs in late summer, between July and September (month 7-9). In the Alps and northern Europe annual minima are in January and February; 


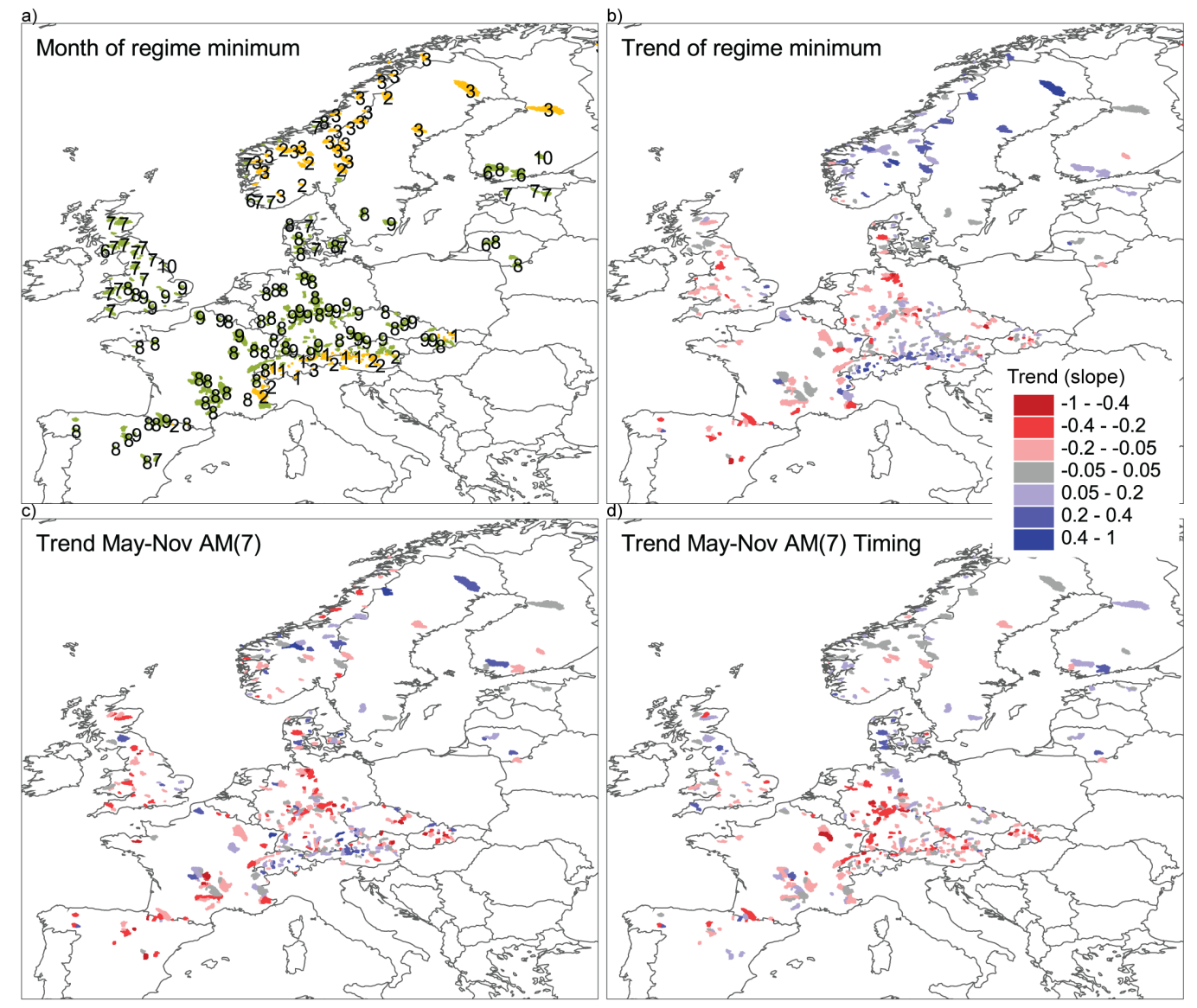

Fig. 3. (a) The month of the regime minimum, (b) trend for mean monthly streamflow for the month of the regime minimum, (c) trend for $\mathrm{AM}(7)$ during May-November, (d) trend for the timing of AM(7) during May-November. All trends are for the period 1962-2004 and given in standard deviations per year.

in central and northern Norway, Sweden and Finland they are mostly in March (Fig. 3a). The composite map of trends in the flow of the minimum month shows clearly that low flows have increased in most winter low-flow regimes and decreased in most summer low-flow regimes (Fig. 3b), although this broad-scale pattern is more complex on a finer scale: in the areas with summer low flow regimes, decreasing trends are often weak, and patterns of directionality are mixed; positive trends predominate around the Baltic Sea and are found locally elsewhere (e.g. for catchments in France and the UK).

The 7-day low flow during the summer season from May to November (Table 2; Fig. 3c) shows more negative trends than the flow in the month of regime minimum, and negative trends in the summer low-flow areas are often stronger (e.g. in the UK and central Germany). In several Norwegian catchments that exhibit an absolute winter minimum, the lowest summer flows have decreased. This is not the case in the Alps, Switzerland, Germany and the western part of Austria, where trends in $\operatorname{AM}(7)$ are mostly positive. In these regions, the lowest summer flows occur late, i.e. in September or October. These months also show opposite trends in monthly streamflow for Norway (negative) and the Alps (positive). The timing of the 7-day summer low flow has shifted to an earlier date (negative trend) in a majority of catchments, particularly in Germany, eastern France, Switzerland, Austria and Slovakia (Fig. 3d). The results for the 30-day low flows, which represent extended-duration periods of low flow and drought, are similar to those of 7-day low flow (see Table 2; maps not shown). For both 7-day and 30-day low flows, the proportion of negative trends substantially exceeds the positive trends in the two most recent study periods, whereas positive trends are more apparent in the earlier periods (notably so in 1942-2004); the aforementioned lack of stations in southern and eastern Europe and a trend shift most visible in France is likely influential. The prevalence of trends towards earlier low flows is also apparent in the 1952-2004 and 1942-2004 periods, but not in the longest period. 


\section{Discussion}

\subsection{European patterns of streamflow trends}

This study found a clear overall pattern of trends in annual streamflow in Europe, with positive trends in northern areas and negative trends in the South and East of the study area. This spatial pattern is broadly consistent with findings from studies on global trends in discharge records of large continental rivers (e.g. Milly et al., 2005; Milliman et al., 2008; Dai et al., 2009), although the observations used in these studies need to be viewed with some caution as indicators of climate-driven changes since they incorporate flow records influenced by river regulation, with variable lengths, different start and end dates of the series, and in some cases combination of discharge observations with climate and land surface model simulations. Such studies found predominantly negative trends in the discharge of selected rivers to the Mediterranean Sea and positive trends in the discharge of selected rivers to the Atlantic Ocean and the North Sea. Resulting maps of continental runoff changes, for example by Dai et al. (2009), assigned the trend of the main river to the catchment area. Results will be different, therefore, from the patterns in the present study based on small catchments. For example, in the headwaters of the Danube in Austria, the Czech Republic and Slovakia, trends in the present study are negative whilst in the dataset by Dai et al. (2009) the main stem Danube and hence the entire catchment appears with a positive trend on the map. Unfortunately, the station density in this study is too sparse to allow such an assessment for most large catchments. However, negative annual streamflow trends in headwater catchments, where positive trends were identified for the main river, were also reported in national trend studies, e.g. by Ayala-Carcedo (1996) for smaller Spanish rivers and by Fiala (2008) for Czech rivers (based on four times more records than used in this pan-European study). For Slovakia, Majeráková et al. (1997) previously reported negative trends for Slovak rivers, mainly due to a reduction in autumn and winter flow. This illustrates the importance of including small basins and seasonal data in the analysis to depict regional-scale variability in trends. Besides the influence of dams and water withdrawals, other natural reasons for differences in trends in headwaters and main rivers may be regime variability among different tributaries, and the role of different processes at different scales.

This study found very coherent patterns in the trends of monthly streamflows. One of the strongest patterns is the regional coherence of increasing winter streamflows. Increasing winter streamflow trends have been reported in national studies for the UK by Hannaford and Marsh $(2006,2008)$ and in southern Germany (KLIWA, 2003), Switzerland (Birsan et al., 2005), Czech Republic (Fiala, 2008), and the Nordic countries (Wilson et al., 2010), where they have been attributed to an increase in mid-winter snowmelt events and/or increasing precipitation.
The spreading of negative trends from the southwest to the entirety of continental Europe and the Baltic countries in April and further again to the UK and southern Norway in May is another key finding of this study. Direct comparisons with the results of previous studies are problematic, as most looked at seasonal averages, e.g. including the very different pattern of March into the spring average. The results suggest that care should be taken when looking at seasonal averages. The distribution of the negative trends over the year for Central Europe identified herein is consistent with the findings of Fiala (2008), on the basis of 65 Czech gauging stations, who found a large majority of stations with positive trends in January-March and September-November, the opposite in April-June, and a mixed pattern in the remaining months. For the Nordic countries, similar changes have been reported by Wilson et al. (2010). The consistently positive trends in Scandinavia in March can be attributed to an earlier onset of snowmelt, a signal shifting to higher elevations and more northerly latitudes in May and June. Hisdal et al. (2007) also found a decrease in spring floods in the Baltic. Negative trends found later in the year can also be an effect of an earlier finish of the snowmelt season.

The general pattern of negative trends dominating throughout the summer months has a few notable exceptions. A mixed picture is shown in the Nordic countries (as also reported by Wilson et al., 2010), the southeast of England and the northeast of France, as well as a few Danish catchments with positive or no trends in June. In these areas the contribution of groundwater to streamflow is high (Hannaford and Marsh, 2006; Renard et al., 2008; Fleig et al., 2010). Various studies have demonstrated the "buffering" impact of groundwater storage in moderating the influence of climate drivers; catchments with less productive aquifers, on the other hand, show a more direct response (e.g. Fleig et al., 2010; Laize et al., 2010). It is possible that increased recharge during winter has a delayed effect on early summer streamflow in these regions, whilst in areas with a lower contribution of groundwater to streamflow, climate plays a larger role in the trends. In southern Germany and the western part of the Alps (Switzerland and France), positive and negative trends are mixed. Trends to less and earlier snowmelt would be expected to be negative. However, a few highly glacierized catchments are known to have experienced increases in streamflow in the Alps, whilst in the low or non-glacierized catchments, which include those used in this study, summer trends appear to vary (Renard et al., 2008; Birsan et al., 2005; Pelliciotti et al., 2010).

The regime changes can help to understand low flows, which has strong implications for water supply, water quality, energy production, water management, aquatic ecology and biodiversity. For example, regions with winter low flow such as northern Scandinavia and the Alps are dominated by increasing trends in low flow (for the month of regime minimum); also, in these areas the lowest summer flows appear not to have decreased as consistently as in other regions 
despite an earlier timing of the lowest summer flows in the Alps. Of these winter low-flow regime areas, only the southeastern and coastal basins in Norway show a decreasing trend in summer low flow. For the majority of areas with summer low flow regimes, it appears that low flows have decreased, a finding which is potentially of significant importance from a water resources management perspective. These results confirm the variability and hence complexity of changes in low flows found in other temperate to cold climate regions (e.g. Burn et al., 2010; Ehsanzadeh and Adamowski, 2010).

For some areas, particularly the UK, Spain, Czech Republic and Slovakia, trends of decreasing low flows suggest a continuation of patterns of increasing streamflow drought severity found in the study by Hisdal et al. (2001), which was based on an earlier version of the European Water Archive (EWA). However, Hannaford et al. (2010) examined the spatial coherence (synchronicity) of regional droughts in Europe and, whilst these authors did not examine trends per se, they documented "drought rich" (e.g. the early 1960s; the early 1970s; 1988-1992) and "drought poor" periods (e.g. the mid-1980s; 1999-2002), which extend across large areas of Europe. Hence, in addition to an overall trend, there is pronounced inter-decadal variability in streamflow droughts. This variability and clustering in time may affect some of the patterns of low flow trends presented herein. The shift to positive trends in southern France for the period 1942-2004, for example, are likely influenced by an exceptionally dry period in the 1940 s, i.e. in the beginning of the study period. This drought episode in southern France has been documented with precipitation data in the European drought catalogue published by Lloyd-Hughes et al. (2010), whilst previous studies attest to the dryness of this period in much of Europe (Lloyd-Hughes and Saunders, 2002; van der Schrier et al., 2006). With a drought-rich phase at the beginning of the 1962-2004 period and the 2003 summer drought at the end the main period of study may be less biased to particular events. As discussed in many previous studies (e.g. Hisdal et al., 2001; Svensson et al., 2006; Chen and Grasby, 2009), trends are invariably sensitive to the period of record studied, and interdecadal variability and individual extremes can be influential. The multiple periods presented in this study mitigate against this to some extent, and results suggest the overall patterns are generally robust to changes in study period, but to bolster this assessment future work could be directed at examining patterns of long-term variability in the few near-natural catchments with very long records, for example by shifting beginning and end dates as e.g. McCabe and Wolock (2002).

\subsection{Comparison with trends in climate drivers}

An examination of the potential influences of changes in climatic drivers on local to regional hydrological response may add to the understanding of the physical resilience of different regional hydrological systems. The annual pattern of streamflow evolution over the study period agrees with observation-based assessments of global rainfall changes, with generally increasing precipitation in higher latitudes, and non-significant or decreasing trends in the lower latitudes of Europe (Zhang et al., 2007; Bates et al., 2008; Klein Tank et al., 2002). For changes in the monthly streamflow regime, in particular where snow is involved, changes in precipitation, temperature and the seasonal shift of snow storage needs to be taken into account. For example, despite a reduction of precipitation, streamflow in a particular month may have increased due to shifted snowmelt timing. Limited accounts of published trend assessments of climate variables are available in such detail. To some degree the national and regional studies discussed in the previous section have attributed streamflow trends to seasonal changes in climate and water balance characteristics and they have shown the difficulty of interpreting the combined effects of changes in precipitation and temperature on hydrology.

As part of the European Climate Assessment and Data (ECA), monthly trend maps for precipitation, temperature and many derived variables, such as indicators of extremes, can be displayed online on demand, for example, for the period of 1961 to 2007 (http://eca.knmi.nl). These ECA trend maps support most of this study's findings; for example, the increasing temperature and precipitation during winter time as a likely cause for increasing streamflow trends and a reduction in precipitation in southern Europe both on an annual and seasonal (JJA) basis as a likely cause for lower flows in that region. Moreover, the trend maps also show a significant increase of mean daily summer temperature (JJA) in the study domain, likely resulting in higher potential evapotranspiration. In catchments with ample water this also leads to higher actual evapotranspiration, which reduces streamflow (e.g. van Lanen et al., 2004) and contributes to the negative trends we found in this study. ECA data can also be used to explore similarities in spatial patterns of climate variables that have not been documented in other studies yet, but have potential for attribution. For example, the decreasing streamflow trends in April in Germany, Switzerland and Austria, as well as the decreasing trends in the UK (and, albeit weaker, in southern Norway) in September and on the west Coast of Norway in October, appear to be linked at least in part to a specific reduction of rainfall in these months. Conversely, the previously discussed anomalies, whereby small areas of positive streamflow trends (France and Germany) occur alongside mostly negative summer streamflow trends in June and July, appear to be related to specific narrow areas of positive precipitation trends.

The tendency towards decreasing streamflow and low flow in summer has some parallels with previous work that has detected a general drying in Europe in summer. The relative roles of temperature and precipitation, however, are not entirely clear. Briffa et al. (2009) showed a tendency towards drying in summer (predominantly in central Europe), in Palmer Drought Severity Index (PDSI) series derived from 
22 very long climate records. These authors concluded that temperature increases have driven this drying trend. Based on standardized precipitation indices (SPI), LloydHughes and Saunders (2002) found that trends in European drought over the twentieth century as a whole are generally non-significant. On the other hand, Bordi et al. (2009) found a trend to increasing drought area in the latter half of the twentieth century as defined by seasonal and bi-annual SPI based on gridded re-analysis model data, although this trend is reported to have reversed more recently (21st century). Sheffield and Wood (2008b) observed non-significant changes in soil moisture droughts in Europe. The difficulties in detection and attribution are also related to the modulation of European precipitation and streamflow by the decadal variability of atmosphere-ocean circulation modes (which may in turn be forced by anthropogenic climate change; e.g. Gillet et al., 2002). Decreasing precipitation and runoff in southern Europe, particularly in Spain and Portugal, has been linked to an increasingly positive North Atlantic Oscillation Index (NAOI) (Trigo et al., 2004; Lopez Moreno et al., 2008). Increasing winter runoff in northern Europe since the early 1960s may also reflect an increasingly positive NAOI (Shorthouse and Arnell, 1997; Hannaford and Marsh, 2008).

Whilst broad-scale links can be found between panEuropean patterns of streamflow trends and previously published work on climate variables, this study has also revealed regional to local variability of streamflow trends. Local impacts and catchment controls may cause a certain degree of physical resilience towards climatic changes. For example, Birsan et al. (2005) demonstrated this phenomenon for Switzerland, finding relations between trends in streamflow and soil depth, glacier coverage, and other catchment characteristics that would dampen or amplify the effect of climatic trends on hydrological regimes. In the present study, regions with a high proportion of catchments with streamflow which is groundwater-dominated appear to be less prone to decreasing trends in summer streamflow, for reasons discussed previously; future work could attempt to explain these localised patterns through analysis of hydrogeological characteristics. Finally, human impacts cannot be completely ruled out as a source of local differences in trend patterns (e.g. local effects such as indirect near-river groundwater use). Land use changes, which have not been taken into account in this study, may affect the hydrology of smaller basins (Blöschl et al., 2007; Beguería et al., 2003; Climent-Soler et al., 2009; Jódar et al., 2010).

\subsection{Assessment of future hydrological change}

Future climate projections have been used to model hydrological changes globally and in Europe. The results of such projections have some parallels with the broad pattern of trends in annual streamflow found in this study, with less spatial detail and variability. Most global maps of future hydrological change have predicted that Europe can be divided into areas with increasing runoff in the North and decreasing runoff in the South (Milly et al., 2005). Bates et al. (2008), in the Intergovernmental Panel on Climate Change (IPCC) technical paper on water, summarized European studies that have found generally similar but more spatially explicit patterns including, for example, decreasing future summer flow in Central and East Europe. The records analysed herein show evidence for this type and direction of change over the past decades. Models have also been employed to predict changes in soil moisture and streamflow extremes, such as drought. Sheffield and Wood (2008a) projected large increases of long-term drought (12 months or more) in soil moisture for the Mediterranean Basin, while changes over higher latitudes are relatively small. Based on modelled PDSI, Burke et al. (2006) projected an overall drying and increase in drought severity for much of Europe, and particularly for southern Europe. Similarly, Lehner et al. (2006) indicated large critical regions in southern and southeastern Europe for which significant changes in river flow drought are expected, and Feyen and Dankers (2009) projected increases in streamflow drought severity and persistence in most parts of Europe. In considering the results of these studies, it is important to critically review the approaches taken and to consider their limitations; results are clearly dependent on the models and scenarios used, and there are fundamental differences between them, which contributes to the wide range of uncertainties associated with future projections. Nevertheless, there is broad agreement in the type and direction of future change projected by these modelling assessments and the studies on the impact of climate change on future drought in soil water and streamflow correspond well with the general patterns of projected runoff change across Europe. However, the effect of climate change on hydrology at the river basin scale is complex, as demonstrated in the present study. Large-scale climate or hydrological models can reproduce broad patterns, but are still unable to capture all relevant spatially-distributed characteristics of physical catchment structures and associated processes, particularly in regimes with storage and release of water across the seasons (snow-dominated and groundwaterdominated regimes). This aspect is particularly important for the prediction and attribution of changes in low flow and hydrological drought.

\section{Conclusions}

With many trend studies addressing either continental discharge to the oceans from the largest continental rivers or national-scale changes, there is little available information on pan-European patterns of observed streamflow trends. This study closed the gap by addressing a newly assembled European dataset of streamflow from small catchments (a scale with direct relevance for catchment-scale water management) with near natural flow regimes, in order to discern 
natural climate variability from other more direct anthropogenic impacts such as impoundments and abstractions. Unfortunately, such data are still difficult to obtain and the availability and accessibility across Europe is highly variable and consequently station density and data coverage needs to be improved. Nevertheless, this study elucidated spatial patterns and regional variability of streamflow trends from the 1930 s up to 2004 , the analysis and interpretation of which has given rise to some important conclusions regarding the sensitivity of regional hydrology across Europe to changing temperature and precipitation patterns. In particular, it was found that annual and seasonal trends need to be carefully distinguished. Annual streamflow trends in many regions appear to reflect wetting trends of the winter months. However, the strong trends of decreasing streamflow were not only found for the southern and eastern regions of the study area, but were also found to be widespread across Europe in spring and summer months. While the consistent increase of winter low flows is likely good news to hydropower production, areas with decreasing early to late summer low flows may face diverse concerns. This study provides a knowledge base of recent trends in regional hydrology in Europe for climate and environmental impact studies. For possible use as a benchmark for spatially distributed simulations with large-scale climate and hydrological models, this knowledge base may enhance model development and increase the confidence that large-scale models are able to represent responses or physical resilience to past climatic changes.

Acknowledgements. River flow data were kindly provided by the Ministry of Agriculture, Forestry, Environment and Water Mangement of Austria, the Czech Hydrometeorological Institute, the National Environmental Research Institute of Denmark, the Estonian Meteorological and Hydrometeorological Institute, the Finnish Environment Institute, the French Ministry of Ecology and Sustainable Development, The Environment Agencies of the German States of Baden-Württemberg, Bayern, Hessen, Niedersachsen, RheinlandPfalz, Sachsen and Thüringen, the Lithuanian Hydrometeorological Service, the Norwegian Water Resources and Energy Directorate, the Slovak Hydrometeorological Institute, CEDEX of Spain, the Swedish Meteorological and Hydrological Institute, and the National River Flow Archive at the Centre for Ecology and Hydrology in the UK.

This study is a contribution to the FRIEND programme. Funding from the following sources contributed to this work: UNESCO-IHP, Division of Water Sciences, Paris (Activity Financing Contract 4500040322) and the EU WATCH project (WATer and global CHange), EC Priority Area "Global Change and Ecosystems", contract number 036946 .

Edited by: G. Di Baldassarre

\section{References}

Ayala-Carcedo, F. J.: Reducción de los recursos hídricos en España por el posible cambio climático, Tecno ambiente, ISSN 11334665, 64, 43-48, 1996.

Bates, B. C., Kundzewicz, Z. W., Wu, S., and Palutikof, J. P.: Climate Change and Water, Technical Paper of the Intergovernmental Panel on Climate Change, IPCC Secretariat, Geneva, Switzerland, 2008.

Beguería, S., López-Moreneo, J. I., Lorente, A., Seeger, M., and García-Ruiz, J. M.: Assessing the effect of climate oscillations and land-use changes on streamflow in the Central Spanish Pyrenees, Ambio, 32, 283-286, 2003.

Birsan, M.-V., Molnar, P., Burlando, P., and Pfaundler, M.: Streamflow trends in Switzerland, J. Hydrol., 314, 312-329, 2005.

Blöschl, G., Ardoin-Bardin, S., Bonell, M., Dorninger, M., Goodrich, M., Gutknecht, D., Matamoros, D., Merz, B., Shand, P., and Szolgay, J.: At what scales do climate variability and land cover change impact on flooding and low flows?, Hydrol. Process., 21, 1241-1247, 2007.

Bordi, I., Fraedrich, K., and Sutera, A.: Observed drought and wetness trends in Europe: an update, Hydrol. Earth Syst. Sci., 13, 1519-1530, doi:10.5194/hess-13-1519-2009, 2009.

Bradford, R. B. and Marsh, T. M.: Defining a network of benchmark catchments for the UK, Proceedings of the Institution of Civil Engineers, Water Mar. Eng., 156, 109-116, 2003.

Briffa, K. R., van der Schrier, G., and Jones, P. D.: Wet and dry summers in Europe since 1750: evidence of increasing drought, Int. J. Climatol., 29, 1894-1905, 2009.

Burke, E. J., Brown, S. J., and Christidis, N.: Modelling the recent evolution of drought and projections for the twenty-first century with the Hadley Centre climate model, J. Hydrometeorol., 7, 1113-1125, 2006.

Burn, D. H., Sharif, M., and Zhang, K.: Detection of trends in hydrological extremes for Canadian watersheds, Hydrol. Process. 24, 1781-1790, 2010.

Chen, Z. and Grasby, S. E.: Impact of decadal and century-scale oscillations on hydroclimate trend analyses, J. Hydrol., 365, 122 133, 2009.

Clarke, R.: On the (mis) use of statistical methods in hydroclimatological research, Hydrolog. Sci. J., 55, 139-144, 2010.

Climent-Soler, D., Holman, I. P., and Archer, D. R.: Application of flow variability analysis to identify impacts of agricultural land use change on the river Axe, southwest England, Hydrol. Res., 40, 380-393, 2009.

Cohn, T. A. and Lins, H. F.: Nature's style: Naturally trendy, Geophys. Res. Lett., 32, L23402, doi:10.1029/2005GL024476, 2005.

Dai, A., Qian, T., Trenberth, K. E., and Milliman, J. D.: Changes in continental freshwater discharge from 1948 to 2004, J. Climate, 22, 2773-2791, 2009.

Demeterova, B. and Skoda, P.: Minimal discharges at Slovak rivers in the period 1961-2000 at the stations of the National Climate Programme, Meteorol. J., 8, 155-163, 2005.

Demeterova, B. and Skoda, P.: Low flows in selected streams of Slovakia, J. Hydrol. Hydromech., 57, 55-69, 2009.

Déry, S. J., Stieglitz, M., McKenna, E. C., and Wood, E. F.: Characteristics and trends of river discharge into Hudson, James, and Ungava bays, 1964-2000, J. Climate, 18, 2540-2557, 2005. 
Déry, S. J., Stahl, K., Moore, R. D., Whitfield, P. H., Menounos, B., and Burford, J. E.: Detection of runoff timing changes in pluvial, nival and glacial rivers of Western Canada, Water Resour. Res., 45, W04426, doi:10.1029/2008WR006975, 2009.

Döll, P., Fiedler, K., and Zhang, J.: Global-scale analysis of river flow alterations due to water withdrawals and reservoirs, Hydrol. Earth Syst. Sci., 13, 2413-2432, doi:10.5194/hess-13-24132009, 2009.

Douglas, E. M., Vogel, R. M., and Kroll, C. N.: Trends in floods and low flows in the United States: impact of spatial correlation, J. Hydrol., 240, 90-105, 2000.

Ehsanzadeh, E. and Adamowski, K.: Trends in timing of low stream flows in Canada: impact of autocorrelation and long-term persistence, Hydrol. Process., 24, 970-980, 2010.

Feyen, L. and Dankers, R.: Impact of global warming on streamflow drought in Europe, J. Geophys. Res., 114, D17116, doi:10.1029/2008JD011438, 2009.

Fiala, T.: Statistical characteristics and trends of mean annual and monthly discharges of Czech rivers in the period 1961-2005, J. Hydrol. Hydromech., 56, 133-140, 2008.

Fiala, T., Ouarda, T. B. M. J., and Hladný, J.: Evolution of low flows in the Czech Republic, J. Hydrol., 393, 206-218, 2010.

Fleig, A. K., Tallaksen, L. M., Hisdal, H., and Hannah, D. M.: Regional hydrological drought in north-western Europe: linking a new Regional Drought Area Index with weather types, Hydrol. Process., in press, 24, doi:10.1002/hyp.7644, 2010.

Gillett, N. P., Graf, H. F., and Osborn, T. J.: Climate change and the North Atlantic Oscillation, in: The North Atlantic Oscillation - Climatic significance and environmental impact, edited by: Hurrell, J. W., Kushnir, Y., Otterson, G., and Visbeck, M., AGU Monograph Series, AGU, 2002.

Haddeland, I., Clark, D. B., Franssen, W., Ludwig, F., Voß, F., Arnell, N. W., Bertrand, N., Best, M., Folwell, S., Gerten, D., Gomes, S., Gosling, S. N., Hagemann, S., Hanasaki, N., Harding, R., Heinke, J., Kabat, P., Koirala, S., Oki, T., Polcher, J., Stacke, T., Viterbo, P., Weedon, G. P., and Yeh, P.: Multi-model estimate of the global water balance: setup and first results, J. Hydrometeorol., submitted, 2010.

Hamed, K. H. and Rao, A. R.: A modified Mann-Kendall trend test for autocorrelated data, J. Hydrol., 204, 182-196, 1998.

Hamlet, A. F., Mote, P. W., Clark, M. P., and Lettenmaier, D. P.: 20th Century Trends in Runoff, Evapotranspiration, and Soil Moisture in the Western U.S., J. Climate, 20, 1468-1486, 2007.

Hannaford, J. and Marsh, T. J.: An assessment of trends in UK runoff and low flows using a network of undisturbed catchments, Int. J. Climatol., 26, 1237-1253, 2006.

Hannaford, J. and Marsh, T. J.: High flow and flood trends in a network of undisturbed catchments in the UK, Int. J. Climatol., 28, 1325-1338, 2008.

Hannaford, J., Lloyd-Hughes, B., Keef, C., Parry, S., and Prudhomme, C.: Examining the large-scale spatial coherence of European drought using regional indicators of rainfall and streamflow deficit, Hydrol. Process., in press, doi:10.1002/hyp.7725, 2010.

Hannah, D. M., Demuth, S., Lanen van, H. A. J., Looser, U., Prudhomme, C., Rees, G., Stahl, K., and Tallaksen, L. M.: Large-scale river flow archives: importance, current status and future needs, Invited Commentary, Hydrol. Process., in press, doi:10.1002/hyp.7794, 2010.
Harvey, K. D., Pilon, P. J., and Yuzyk, T. R.: Canada's reference hydrometric basin network (RHBN), in: Partnerships in water resources management, Canadian Water Resources Association (CWRA)'s 51st Annual Conference, Halifax, Nova Scotia, June, 1999.

Hisdal, H., Stahl, K., Tallaksen, L. M., and Demuth, S.: Have droughts in Europe become more severe or frequent?, Int. J. Climatol., 21, 317-333, 2001.

Hisdal, H., Holmqvist, E., Jónsdóttir, J. F., Jónsson, P., Järvet, A., Lindström, G., Kolcova, T., Kriauciuniene, J., Kuusisto, E., Lizuma, L., Meilutyte-Barauskiene, D., Reihan, A., and Roald, L. A.: Climate change signals in streamflow data in the Nordic and Baltic region, in: Proceedings of the Third International Conference on Climate and Water, edited by: Heinonen, M., 36 September 2007, SYKE, Helsinki, Finland, 182-187, 2007.

Hunger, M. and Döll, P.: Value of river discharge data for globalscale hydrological modeling, Hydrol. Earth Syst. Sci., 12, 841861, doi:10.5194/hess-12-841-2008, 2008.

Jódar, J., Carrera, J., and Cruz, A.: Irrigation enhances precipitation at the mountains downwind, Hydrol. Earth Syst. Sci., 14, 20032010, doi:10.5194/hess-14-2003-2010, 2010.

Khaliq, M. N., Oaurda, T. B. M. J., Gachon, P., and Sushama, L.: Temporal evolution of low flow regimes in Canadian rivers, Water Resour. Res., 44, W08436, doi:10.1029/2007WR006132, 2008.

Klein Tank, A. M. G., Wijngaard, J. B., Konnen, G. P., Bohm, R., Demaree, G., Gocheva, A., Mileta, M., Pashiardis, S., Hejkrlik, L., Kern-Hansen, C., Heino, R., Bessemoulin, P., MullerWestermeier, G., Tzanakou, M., Szalai, S., Palsdottir, T., Fitzgerald, D., Rubin, S., Capaldo, M., Maugeri, M., Leitass, A., Bukantis, A., Aberfeld, R., VanEngelen, A. F. V., Forland, E., Mietus, M., Coelho, F., Mares, C., Razuvaev, V., Nieplova, E., Cegnar, T., López, J. A., Dahlstrom, B., Moberg, A., Kirchhofer, W., Ceylan, A., Pachaliuk, O., Alexander, L. V., and Petrovic, P.: Daily dataset of 20th-century surface air temperature and precipitation series for the European Climate Assessment, Int. J. Climatol., 22, 1441-1453, 2002

KLIWA: Langzeitverhalten der mittleren Abflüsse in BadenWürttemberg und Bayern, Karlsruhe, http://www.kliwa.de/ download/KLIWAHeft3.pdf, last access: 27 November 2010, 93 pp., 2003.

Koutsoyiannis, D.: Climate change, the Hurst phenomenon, and hydrological statistics, Hydrolog. Sci. J., 48, 3-24, 2003.

Koutsoyiannis, D.: Nonstationarity versus scaling in hydrology, J. Hydrol., 324, 239-254, 2006.

Koutsoyiannis, D. and Montanari, A.: Statistical analysis of hydroclimatic time series: Uncertainty and insights, Water Resour. Res., 43, W05429, doi:10.1029/2006WR005592, 2007.

Krakauer, N. Y. and Fung, I.: Mapping and attribution of change in streamflow in the coterminous United States, Hydrol. Earth Syst. Sci., 12, 1111-1120, doi:10.5194/hess-12-1111-2008, 2008.

Laizé, C. R. L. and Hannah, D. M.: Modification of climate-river flow associations by basin properties, J. Hydrol., 389, 186-204, 2010.

Lehner, B., Döll, P., Alcomo, J., Henrichs, T., and Kaspar, F.: Estimating the impact of global change on flood and drought risk in Europe: a continental integrated analysis, Climatic Change, 75, 273-299, 2006. 
Lins, H. F. and Slack, J. R.: Streamflow trends in the United States, Geophys. Res. Lett., 26, 227-230, 1999.

Lloyd-Hughes, B. and Saunders, M. A.: A drought climatology for Europe, Int. J. Climatol., 22, 1571-1592, 2002.

Lloyd-Huges, B., Hannaford, J., Parry, S., Keef, C., and Prudhomme, C.: Spatial coherence of European Droughts, Stage 1: UK and European Drought Catalogues, Environment Agency Science Report, SC070079/SR1, 66 pp., 2010.

Lohmann, D., Mitchell, K. E., Houser, P. R., Wood, E. F., Schaake, J. C., Robock, A., Cosgrove, B. A., Sheffield, J., Duan, Q., Luo, L., Higgins, R. W., Pinker, R. T., and Tarpley, J. D.: Streamflow and water balance intercomparisons of four land surface models in the North American Land Data Assimilation System project, J. Geophys. Res., 109, D07S91, doi:10.1029/2003JD003517, 2004.

Lopez-Moreno, J. and Vicente-Serrano, S. M.: Positive and negative phases of the wintertime North Atlantic Oscillation and drought occurrence over Europe, A multitemporal-scale approach, J. Climate, 21, 1220-1243, 2008.

Majercakova, O., Fendekova, M., and Leskova, D.: The variability of hydrological series due to extreme climatic conditions and the possible change of the hydrological characteristics with respect to potential climate change, in: FRIEND'97 - Regional Hydrology: concepts and Models for Sustainable Water Management, IAHS AISH P., 246, 59-65, 1997.

Milliman, J. D., Farnsworth, K. L., Jones, P. D., Xu, K. H., and Smith, L. C.: Climatic and anthropogenic factors affecting river discharge to the global ocean, 1951-2000, Global Planet. Change, 62, 187-194, 2008.

Milly, P. C. D., Dunne, K. A., and Vecchia, A. V.: Global pattern of trends in streamflow and water availability in a changing climate, Nature, 438, 347-350, 2005.

Morán-Tejeda, E., Ceballos-Barbancho, A., and Llorente-Pinto, J. M.: Hydrological response of Mediterranean headwaters to climate oscillations and land-cover changes: The mountains of Duero River basin (Central Spain), Global Planet. Change, 72, 39-49, 2010.

Nilsson, C., Reidy, C. A., Dynesius, M., and Revenga, C.: Fragmentation and Flow Regulation of the World's Large River Systems, Science, 308, 405-408, 2005.

Pellicciotti, F., Bauder, A., and Parola, M.: Effect of glaciers on streamflow trends in the Swiss Alps, Water Resour Res., 46, W10522, doi:10.1029/2009WR009039, 2010.

Radziewski, M. and Kundzewicz, Z. W.: Detectability of changes in hydrological records, Hydrolog. Sci. J., 49, 39-51, 2004.

Renard, B., Lang, M., Bois, P., Dupeyrat, A., Mestre, O., Niel, H., Sauquet, E., Prudhomme, C., Parey, S., Paquet, E., Neppel, L., and Gailhard, J.: Regional methods for trend detection: assessing field significance and regional consistency, Water Resour. Res., 44, W08419, doi:10.1029/2007WR006268, 2008.

Schmocker-Fackel, P. and Naef, F.: More frequent flooding? Changes in flood frequency in Switzerland since 1850, J. Hydrol., 381, 1-8, doi:10.1016/j.jhydrol.2009.09.022, 2010.

Sen, P. K.: Estimates of regression coefficients based on Kendall's tau, J. Am. Stat. Assoc., 63, 1379-1389, 1968.

Sheffield, J. and Wood, E. F.: Projected changes in drought occurrence under future global warming from multi-model, multiscenario, IPCC AR4 simulations, Clim. Dynam., 13, 79-105, 2008a.
Sheffield, J. and Wood, E. F.: Global trends and variability in soil moisture and drought chracateristics, 1950-2000, from observation-driven simulations of the terrestial hydrologic cycle, J. Climate, 21, 432-458, 2008b.

Shorthouse, C. A. and Arnell, N. W.: Spatial and temporal variability on European river flows and the North Atlantic Oscillation, FRIEND'97 - Regional Hydrology: Concepts and Models for Sustainable Water Resource Management, IAHS-AISH P., 246, 77-85, 1997.

Slack, J. R. and Landwehr, J. M.: Hydro-Climatic Data Network (HCDN): A U.S. Geological Survey Streamflow Data Set for the United States for the Study of Climate Variations, 18741988, Tech. rep., http://pubs.usgs.gov/wri/wri934076/, last access: 29 November 2010, USGS Open-File Report 92-129, 1992.

Stahl, K., Hisdal, H., Tallaksen, L. M., van Lanen, H. A. J., Hannaford, J. and Sauquet, E.: Trends in low flows and streamflow droughts across Europe, UNESCO Report, Paris, 2008.

Stahl, K., Steinbrich, A., and Schwab, M.: Catchment boundaries for the FRIEND European Water Archive: delineation based on CCM2, GRDC Report, Global Runoff Data Centre, Koblenz, in preparation, 2010.

Svensson, C., Hannaford, J., Kundzewicz, Z. W., and Marsh, T.: Trends in river floods: why is there no clear signal in observations?, In: Frontiers in Flood Research, Proceedings of Kovacs Colloquium, Paris, June 2006, IAHS-AISH P., 305, 1-18, 2006.

Theil, H.: A rank-invariant method of linear and polynomial regression analysis, Indagat. Math. New Ser., 12, 85-91, 1950.

Trigo, R. M., Pozo-Vazquez, D., Osborn, T. J., Castro-Diez, Y., Gamiz-Fortis, S., and Esteban-Parra, M. J.: North Atlantic oscillation influence on precipitation, river flow and water resources in the Iberian peninsula, Int. J. Climatol., 24, 925-944, 2004.

Troy, T. J., Wood, E. F., and Sheffield, J.: An efficient calibration method for continental-scale land surface modeling, Water Resour. Res., 44, W09411, doi:org/10.1029/2007WR006513, 2008

van Lanen, H. A. J., Kašpárek, L., Novický, O., Querner, E. P., Fendeková, M., and Kupczyk, E.: Human Influences, in: Hydrological Drought, Processes and Estimation Methods for Streamflow and Groundwater, edited by: Tallaksen, L. M. and van Lanen, H. A. J., Developments in Water Science, 48, Elsevier Science B. V., 347-410, 2004.

Viglione, A., Borga, M., Balanbanis, P., and Blöschl, G.: Barriers to the exchange of hydrometeorological data in Europe: Results from a survey and implications for data policy, J. Hydrol., 394, 63-77, 2010.

Vogt, J. V., Soille, P., de Jager, A. L., Rimaviciute, E., and Mehl, W.: A pan-European River and Catchment Database, EC-JRC Report EUR 22920 EN, http://ccm.jrc.ec.europa.eu/ documents/CCM2-Report_EUR-22920-EN_2007_STD.pdf, last access: 29 November 2010, Luxembourg, 120 pp., 2007.

von Storch, V.: Misuses of statistical analysis in climate research, in Analysis of climate variability: application of statistical techniques, edited by: von Storch, H., and Navarra, A., SpringerVerlag, Berlin, 11-26, 1995.

Wilson, D., Hisdal, H., and Lawrence, D.: Has streamflow changed in the Nordic countries? - Recent trends and comparisons to hydrological projections, J. Hydrol., 394, 334-346, 2010. 
Yue, S. and Wang, C. Y.: Regional streamflow trend detection with consideration of both temporal and spatial correlation, J. Climatol., 22, 933-946, 2002.

Zhang, X., Harvey, D., Hogg, W. D., and Yuzyk, T. H.: Trends in Canadian Streamflow, Water Resour. Res., 37, 987-998, 2001.
Zhang, X., Zwiers, F. W., Hegerl, G. C., Lambert, F. H., Gillett, N. P., Solomon, S., Stott, P. A., and Nozawa, T.: Detection of human influence on twentieth-century precipitation trends, Nature, 448, 461-465, 2007. 